\title{
MyastheniaGravis(MG) in a patient with Juvenile Idiopathic Arthritis
}

\author{
Christiaan Scott ${ }^{1 *}$, Asgar Kalla ${ }^{2}$ \\ From 18th Pediatric Rheumatology European Society (PReS) Congress \\ Bruges, Belgium. 14-18 September 2011
}

\section{Introduction}

Myasthenia Gravis associated with Juvenile Idiopathic Arthritis has been reported in children with various subtypes of JIA $[1,2]$.

\section{Methods}

We present a 17year old girl known with Rheumatoid Factor Positive Polyarticular Juvenile Idiopathic Arthritis for 4 years who developed Myasthenia Gravis while on therapy with Methotrexate, Prednisone and Ibuprofen.

\section{Results}

This patient presented to the emergency room with a respiratory infection. She had been feeling weak and had noticed tongue weakness and difficulty swallowing, which had worsened significantly since the respiratory infection.

On examination she was found to have clinical signs of Right Middle Lobe pneumonia and was found to be weak, especially in her proximal muscle groups. She had bilateral ptosis as well as facial weakness. She had active arthritis in multiple joints. Despite intravenous antibiotics and full supportive management she deteriorated rapidly, and within 12 hours required intubation and ventilation.

The patient was found to have high $\mathrm{ACH}$ receptor antibodies and responded dramatically to pyridostygmine therapy, confirming the diagnosis of MG. High prednisone and azathioprine have been added to her regime.

\section{Discussion}

Myasthenia Gravis is a rare association with JIA. The majority of cases appear to be associated with oligo-

${ }^{1}$ Red Cross War Memorial Childrens Hospital, Cape Town, South Africa Full list of author information is available at the end of the article articular JIA. This patient presented after an acute infection and a recent worsening in her JIA symptoms.

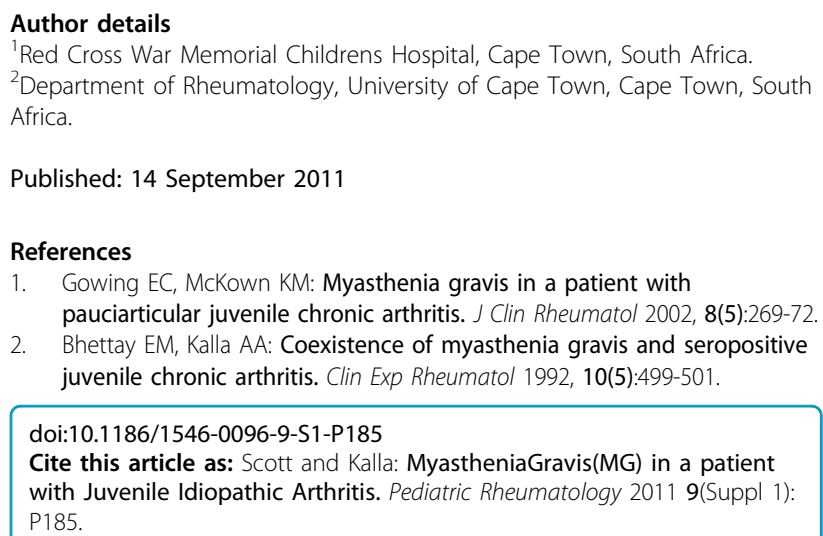

${ }^{1}$ Red Cross War Memorial Childrens Hospital, Cape Town, South Africa. ¿Department of Rheumatology, University of Cape Town, Cape Town, South Africa.

Published: 14 September 2011

\section{References}

1. Gowing EC, McKown KM: Myasthenia gravis in a patient with pauciarticular juvenile chronic arthritis. J Clin Rheumatol 2002, 8(5):269-72.

2. Bhettay EM, Kalla AA: Coexistence of myasthenia gravis and seropositive juvenile chronic arthritis. Clin Exp Rheumatol 1992, 10(5):499-501.

doi:10.1186/1546-0096-9-S1-P185

Cite this article as: Scott and Kalla: MyastheniaGravis(MG) in a patient with Juvenile Idiopathic Arthritis. Pediatric Rheumatology 2011 9(Suppl 1): P185.

Submit your next manuscript to BioMed Central and take full advantage of:

- Convenient online submission

- Thorough peer review

- No space constraints or color figure charges

- Immediate publication on acceptance

- Inclusion in PubMed, CAS, Scopus and Google Scholar

- Research which is freely available for redistribution

\section{() Biomed Central}

